Noman 2019, 37(2), 15-23

Revista de Psicologia, Ciències de l'Eduació i de l'Esport

ISSN: $1138-3194$

CFacultat de Psicologia, Ciències de l'Educació i de l’Esport Blanquerna

Universitat Ramon Llull

(c) (i) (2)

\title{
The impact of the flipped classroom in higher education: a case study
}

\author{
María José Sosa \& Dolores Narciso \\ Universidad de Extremadura
}

Received: 2019-5-31

Accepted: 2019-10-3

The impact of the flipped classroom in higher education: a case study

Summary. Some of the new teaching models that have emerged, including the Flipped Classroom, can be key to reversing traditional educational practices. However, it is necessary to analyse in detail how these educational experiences are being implemented in the classroom, and how this is affecting students' learning. The present research uses a case study methodology. The objective is to analyse a higher education course taught using flipped classroom methodology and to assess the impact of the implementation of said pedagogical model on the students' formative process. The study used a data collection instrument based on a structured interview and a data analysis strategy based on the Grounded Theory. In general, the results show that students tend to express positive opinions and a good degree of satisfaction with their experiences with this pedagogical method. Most students confirm that the method successfully stimulates cooperative learning and favours the practical acquisition of knowledge, stimulating in turn the development of a series of key competences in the educational process, along with capabilities such as organisation, autonomy and responsibility, among others.

Keywords: Flipped classroom; active learning; teaching methods; higher education

\section{Impacto del flipped classroom en la formación superior: un estudio de caso}

Resumen. En la actualidad, están surgiendo nuevos modelos de enseñanza emergentes como el Flipped Classroom que pueden ser la clave para revertir las prácticas educativas tradicionales. No obstante, es necesario analizar de manera pormenorizada cómo se están desarrollando estas experiencias didácticas en el aula, y cómo está afectando al aprendizaje del alumnado. Se presenta, a continuación, una investigación de corte cualitativa, cuyo objetivo es analizar una práctica de Flipped Classroom en la Educación Superior y determinar el impacto que supone en el alumnado la implementación de dicho modelo pedagógico en su proceso formativo. Para ello, se ha optado por un instrumento de recogida de datos basado en una entrevista estructurada, y una estrategia de análisis de datos basada en la Teoría Fundamentada. Los resultados obtenidos demuestran de manera genérica que los estudiantes tienen una valoración positiva y satisfactoria sobre sus experiencias con este método pedagógico. Se afirma que se favorece la adquisición de conocimientos de manera práctica y aumenta el rendimiento académico, estimulando a su vez el desarrollo de una serie de competencias claves en el proceso educativo como la capacidad de organización, autonomía, responsabilidad, entre otras. Además, promueve el aprendizaje cooperativo y relaciones interpersonales más exitosas entre el alumnado y con el docente, así como el desarrollo de emociones más positivas y la motivación hacia el aprendizaje.

Palabras clave: flipped classroom; aula invertida; aprendizaje activo, métodos didácticos; Educación Superior 


\section{Introduction}

Recent years have witnessed the emergence of a number of new teaching models, including the Flipped classroom (Jensen et al., 2018; Sosa \& Palau, 2018b), which might be the key to overcoming some of the shortcomings of traditional educational practices (Blasco, Lorenzo, \& Sarsa, 2016, Sánchez, Solano, \& González, 2016).

Writing about the flipped classroom, González and Carrillo (2016) have highlighted the method's "great potential..., which is shaped by the possible merger of ICT use with active learning and participatory methodologies, wherein students regulate their own learning processes, under the teacher's guidance" (p. 43). Researchers and educators have pointed to a number of positive effects of the use of the this kind of emerging teaching model, which explains in part why the use of these techniques is becoming more and more widespread. A review of the academic literature on the flipped classroom (FC) methodology shows that most researchers have found this model to have positive effects on students, leading to improved academic performance and more effective learning (O'Flaherty \& Phillips, 2015; Martín \& Santiago, 2016; Akçayır \& Akçayır 2018; Sergis, Sampson \& Pelliccione, 2018; Awidi \& Paynter, 2019; Sola, Aznar, Romero, \& Rodríguez, 2019).

Meanwhile, other studies of the FC model have shown that it can be more broadly beneficial to all aspects of the teaching-learning process (Simon, Ojando, Ávila, Miralpeix, López, \& Prats, 2016; Díaz, Martín \& Sánchez, 2017) and that the methodology allows teachers to optimise their use of class time and focus more on active learning activities (Blasco et al., 2016; Long, Cummins, \& Waugh, 2016; Sánchez, Ruiz \& Sánchez, 2017). The model has also been found to foster positive attitudes among students, engendering greater participation and motivation to learn (Evseeva \& Solozhenko, 2015, Martín \& Santiago, 2016; Akçayır \& Akçayır, 2018). It is worth noting that a number of scholars have also focused their analyses on how the inverted classroom can adapt to serve the needs of different individuals and how it fosters a more personalised style of education (Martín \& Núñez del Rio, 2015; Simón et al., 2016). One study in this vein by Yoshida (2016) found that students felt that flipped allowed them to study at their own pace, improved their understanding of course contents boosted the effectiveness of in-person classes. This teaching model grants students an important role in managing their own teaching and learning process. When they attend classes, they already possess some theoretical knowledge of the subject, which allows them to gain greater understanding (Simón et al., 2016).

However, in order for the flipped classroom methodology to be a success, both teachers and students must take on new and different roles throughout the educational process. This explains why the widespread scholarly interest in the more active role played by students in a flipped classroom. Researchers have underlined how these kinds of educational experiences can be effective at instilling in students a strong sense of responsibility, motivation and participation, all of which help students learn to learn (Moraros, Islam, Yu, Banow, \& Schindelka, 2015; O'Flaherty \& Phillips, 2015; Tourón \& Santiago, 2015; Blasco et al., 2016; Perdomo, 2016; Andrade \& Chacón, 2018; Serrano \& Casanova, 2018; Simon et al., 2018).

In short, under this learning model students leave behind their traditionally passive role and become more active players in their own learning (Serrano \& Casanova, 2018, p. 158). Along these lines, researchers such as Zainuddin and Perera (2017) have found that students in flipped classrooms were more likely to feel they were competent to complete tasks and activities. As such, they were more motivated to cultivate their own autonomous learning processes than students in more traditional classrooms. Other findings indicate that interpersonal relations in the flipped classroom are more rewarding and productive than in conventional classrooms, as flipped classroom students learn to interact more effectively with their peers (Evseeva \& Solozhenko, 2015; Moraros et al., 2015). The results of another study by Sun and $\mathrm{Wu}$ (2016) indicated that small group discussions allowed students to clear up uncertainties and establish interactions more effectively than in conventional classrooms.

Despite the central role of students, teachers also play a key role in the flipped classroom. Researchers have found that this method calls for a great deal of dedication on the part of teachers (González, Jeong, Gallego, \& Cañada, 2018), who must take on the role of mediators between knowledge and their students (Simon et al., 2018; Luo, Yang, Xue, \& Zuo, 2019). Throughout the learning process, the role of the teacher is one of active collaboration, providing students with the guidance, scaffolding and feedback they need (Tourón \& Santiago, 2015; Chilingaryan \& Zvereva, 2017; Luo, Yang, Xue, \& Zuo, 2019). In short, the teacher must abandon his or her role as an individual leader and embrace the role of a leader of transformational change (Simon et al., 2018). In other words, the method represents an ideological challenge to the traditional role of the teacher (Chilingaryan \& Zvereva, 2017).

Most research on the topic has found that both students and teachers tend to express satisfaction with their flipped classroom experiences. Some scholars have suggested that the model can exert a direct influence on the emotions that students experience at school (Martín \& Nuñez del Río, 2015, O’Flaherty \& Phillips, 2015). The results of another study by González et al. (2018) provided further confirmation of the significant emotional effects of implementing a flipped classroom model. According to this study, students tend to express positive emotions with regard to classes using flipped classroom methodology, calling them fun, interesting and practical, while students whose classes were conducted using traditional methods were more likely to 
have negative emotional reactions and label their experiences as overwhelming, complicated, monotonous and boring (González et al., 2018).

Nonetheless, there is evidence in the literature that not all students react positively to FC methods. A study by McNally et al. (2017) underlined the potential for this educational approach to awaken a degree of resistance, undermining students' motivation. In the same vein, Sosa and Palau (2018a, 2018b) have observed that there is no evidence of a unanimous consensus among students with regard to the flipped classroom. On the contrary, there seem to be two distinct groups of students with opposing viewpoints. One group embraces the new model, while the other defends a more traditional methodology. In their study of a flipped classroom project, Goedhart, Blignaut-van, Moser, \& Zweekhorst (2019) recount that, while the experience overall was a positive one, not all the students agreed that the FC had contributed to improving their learning results. Elsewhere, Strayer (2012) found that students who had completed a class using a FC model were unsatisfied with the way the class's structure had served to guide them through their learning tasks.

When the flipped classroom is met with such negative reactions, it might be due to the characteristics of the students themselves. For example, they might not have the academic experience or the scientific reasoning and autonomous learning required of them in a flipped classroom (Jensen, Holt, Sowards, Ogden, \& West, 2018; Goedhart et al., 2019). Some studies have also suggested that the implementation of this model might be hindered because of resistance to the necessary changes in both students' and teachers' roles. A study by Long, Cummins and Waugh (2016) found that after carrying out FC projects teachers reported a lack of preparation by students before class and an unwillingness on the part of the students to commit to their new, more active role. Some scholars have addressed ways to ensure that the teaching model does not fall victim to these issues, with studies by Sánchez, Ruiz and Sánchez (2016) and Martín and Santiago (2016) warning that students need clearly defined and well-structured guidance if the method is to be successful.

With this range of somewhat contradictory results in mind, it is hard to say with any confidence how or under what conditions the flipped classroom approach represents a valuable pedagogical alternative. The purpose of this paper is to enhance our knowledge and understanding of how students experience this method in the classroom and to determine whether the model has a positive impact on the teaching and learning process, as some other researchers have found.

\section{Method}

\section{Research objectives and research questions}

The aim of this study is to determine the impact of the use of the flipped classroom model on the teaching and learning process. To this end, the paper will seek to answer the following research questions: a) What impact does the use of this pedagogical model have on students?; b) How doe students assess they roles they have taken on and the interactions they have had in a flipped classroom?; y c) What attitudes and emotions are displayed by those involved?

\section{Research methodology: Case study}

In light of the particularities of this research, the method adopted was a qualitative approach within the interpretive paradigm. The strategy was to gather the opinions of students who had experienced a class taught using this pedagogical model. In order to accomplish this, a case study was carried out to focus our observations of the phenomenon on students who have experience with the flipped classroom model in one of their subjects. In terms of the procedure followed, at the start of the course the students were informed about the basic principles of the flipped classroom method and given a calendar with information about the work they would do throughout the course. At the end of the semester, after the students had experienced the pedagogical methodology, an online interview was administered during class time to gather data for this study.

\section{Sample}

This study made use of an intentional, non-probabilistic sample made up of first-year students in the Primary Education degree at the University of Extremadura who had taken a class using the flipped classroom model. It should be noted that all the students registered for the subject took part in the study, meaning that the total sample consisted of 105 students divided into two groups.

Some of the demographic characteristics of the sample are as follows:

a) The participants ranged in age from 17 to 38 , but $50 \%$ of them were 18 years old.

b) The group consisted of 52.9\% male students and $47.1 \%$ female students.

\section{Data collection instrument}

A previously existing structured interview tool designed by Sosa y Palau (2018a, 2018b) was used to collect data on students' perceptions of the flipped classroom.

As Sosa and Palau (2018) have written, the instrument is made up of 40 short questions related to the flipped classroom and dealing with the following categories: satisfaction, motivation, interaction/collaboration with peer and the teacher, and digital materials/technological tools.

As mentioned above, the interview was administered online via a Google Form, thus allowing for quick data collection. This method does imply sacrificing the expressiveness and immediacy of verbal responses. 


\section{Analytical strategy}

The strategy employed to analyse the data collected was based on constant comparison method emerging from Grounded Theory. This data interpretation procedure consists of three distinct processes: a) open coding, with the creation of a series of categories; b) axial coding, with the creation of interpretive memoranda; and c) selective coding, through the construction of an emerging framework to narrate the relations (Strauss \& Corbin, 2002; San Martín, 2014).

\section{Results}

Below, the results of the various categories studied are presented and grouped into three aspects that were considered especially relevant: a) Methodological designs and learning; b) Motivation and satisfaction; c) Student/teacher interaction.

\section{Methodological design and learning}

The most commonly occurring themes in students' descriptions of the methodological design used in the implementation of the flipped classroom model during the course were as follows: studying at home $\left(12^{1}\right)$ and doing classroom activities to put the course's theoretical contents into practice (15). The activities that garnered the most positive reactions among the students included the use in the classroom of Kahoot quizzes, which forced them to keep pace with the syllabus in their individual study (34), the creation of a video documentary that afforded them the opportunity to apply the contents in a practical context (11), and the creation of conceptual maps or diagrams, which helped enhance their understanding of the subject matter (6).

"We worked every day on what we had studied, after taking a quiz with Kahoot, which makes you retain what you have learned much better because you have to apply it. I would highlight the conceptual mapping activity, which I really enjoyed." (MET_ACTV, P28).

In general, most students characterised the role they had played during the class as that of active participants (51) throughout the process, and they reported having played a central part in the process of constructing their own learning and planning their knowledge.

"I played an active role as a student, studying at home and showing what I knew in the Kahoot quizzes and the assignments" (AL_PAPEL, P40).

With regard to the practical activities completed in class, it is worth noting that 102 students felt that spending class time on such activities had benefitted their learning, as it represented an opportunity to internalise and consolidate what they had learned (38), made for more entertaining classes (9), gave them the

1. Explanatory note: the numbers in parentheses, such as (12), (35), (7) refer to the number of students whose responses contained the same idea within a subcategory. chance to raise questions resolve uncertainties in real time (6), and represented an educational model that was both easy to apply and conducive to the acquisition of knowledge (10) "because when you do practical, applied activities, that's really when your questions about the contents arise, and it's much more dynamic" (PRAC_ $C L A S$, P63). However, there were two students who expressed the opinion that spending class time on practical activities had not benefitted their learning, one arguing that "I think it would have been better for me to have a normal class and to the activities at home, because they weren't difficult and we could have done them without too much explanation." (PRAC_CLAS, P34).

Nonetheless, 97 of the students did say that these activities had led to improvements in their learning processes, 65 said they had found the course's educational model to meet their individual needs and respect their different paces of learning, with one reporting that "I learned in my own way and at my own pace," (MET_IND, P16). Meanwhile 31 of the respondents reported that the flipped classroom methodology was able to "adapt to [their] learning needs," (APRE_IND, P45). Still, some students did level criticisms: "I don't really think there is a pace of learning. The only question is whether you've done the work or not. The same failures as traditional education" (MET_IND, P75).

When asked to name the most useful aspect of the flipped classroom model, a large number of the students characterised this pedagogical method as follows:

It improves teamwork abilities (cooperative work) (31): "It fosters teamwork, and thanks to that, we've developed strong abilities to work as a team, which will be very beneficial in the years to come" (MET ACTV, P69).

It fosters acquisition of the contents and promotes meaningful learning (18): "The fact that you work at home and in class makes studying in both places more enjoyable, because you mix practical applications with studying, and this makes it more entertaining and easier" (MET_UTIL, P 21).

It fosters students' autonomy (9): "Improves autonomy and understanding through group work" (MET_UTIL, P 5).

The practical activities made the class fun and dynamic (11): "It's a more dynamic way to learn, because you're taught by your classmates, who use the same vocabulary as you." (MET_UTIL, P82).

Freedom to do the activities (4), allowing students to organise their own work (4): "When you have so much freedom, you have to be responsible and know how to organise yourself" (MET_UTIL, P 71).

Meanwhile, some of the other learning elements enhanced by the flipped classroom, mentioned less frequently, include the following: communicative competency, creativity, responsibility, self-confidence with regard to learning, the ability to optimise the use of class time and the placing of the student at the centre of the educational process.

In general, the students did not report having faced any difficulties over the course of the implementation 
of the flipped classroom model (93). Most of the students (84) said that the use of this model had helped them achieve a better grade than they would have otherwise, while two students maintained that the method offered an opportunity to improve grades depending on "the effort you make in the course" (CALFI, P44). A small group of students, however, did report having experienced problems during the process, including three of them who said that "at the beginning, like in any class, you have to get used to the new methodologies that you are going to use," (MET_DIF, P82). Two others said that they had faced difficulties associated with the changes implicit in this methodology, with one stating that "Before I study something, I need someone to explain it to me and take notes, rather than starting from scratch "(MET_DIF, P34), and another recounting difficulties with group work because of a failure to "come to agreements with others on certain issues" (MET_DIF, P 5).

For the most part, though, the students found the classes to be well planned and did not identify any areas especially in need of improvement (59). However, some students did offer some ideas for ways to make the flipped classroom methodology more effective. Some of these proposals included a suggestion to improve the contents of both the theoretical and practical activities and a recommendation that teachers offer a summary in class of the most important theoretical aspects of each unit (7).

Most students (59) recated positively to the assessment process, with many of them (38) expressing satisfaction and saying there was nothing about it they would change. According to one respondent, "The assessment was appropriate and in accordance with the methodology, because the class is very practical, and we have learned via practical activities," (MET_VAL, P82).

In terms of the hours of study the students had devoted to the class, it is worth underlining that most of the students felt that this method had implied a greater dedication of time, which went along with increased learning (41). Some students (22) reported having spent two to four hours a week on the class, while others (9) put the figure at an hour a day.

"Three hours a week, yes that's an increase, but I was working to understand concepts instead of memorising them" (MET_DEDIC, P72).

\section{Motivation and satisfaction}

The students' responses indicate that 104 people found the flipped classroom method interesting. Additionally, 94 students expressed a willingness to sign up for another class taught using this method. Most (94) considered the flipped classroom better and more effective than traditional teaching methodologies, and many (33) found that the method made for more dynamic and entertaining classes than conventional teaching styles, because "You're not just sitting there listening to the profesor for hours and hours. We ourselves are doing the work, seeking out information and learning on our own," (SAT_TRA, P65).
However, a small minority of students (2) did express a preference for a more traditional methodology, saying that "I find it more useful to take notes in class and use my free time to do activities, not the other way around," (SAT_TRA P34).

With regard to their learning during their experience with the flipped classroom method, 100 students reported feeling happy or excited to learn in this way. Some (15) felt that the FC method was fun/entertaining, while others (29) called it different or new "because it breaks with the traditional model," (ACTI_APRN, P22). A student observed that the method "is different from what we're used to, because it's not boring in that you don't have to spend two hours listening to lectures, but instead you learn from theoretical and practical activities, " (ACTI_ APRN, P43). Additionally, some students (97) report having felt motivated, "because you learn more by doing research and seeking out the information you need to do the various activities," (MOT_CONTEN, P31).

Nonetheless, some students were not satisfied with the pedagogical method, with one saying that "once again, whenever I have to study at home and it doesn't help me to understand the concepts in class, I feel less motivated," (MOT_CONTEN, P75).

When asked to examine their own attitudes with regard to the class, most students (72) gave themselves good self-assessments. "My attitude was positive, and I hoped that I would be able to apply what I learned in the class in the future," (MOT_APREN, P29). Furthermore, the most frequently expressed emotions were positive (25). Most prominent among these emotions were joy (19), enthusiasm (18) and motivation (20). However, some students did report experiencing negative emotions such as intrigue (8) and nervousness (3) due to their unfamiliarity with the methodology.

"Nervousness, but at the same time curiosity to see what would happen each day," (EMO, P42).

"Joy and enthusiasm, because it was different from traditional methods." (EMO, P94).

\section{Teacher/student interaction}

The results obtained with regard to the interaction among peers show that most students found their communication with their classmates to be very good (49), good (44), perfect (5) or acceptable (4). The explanation for these findings lies in fact that all the members of the group were working toward a common goal, causing them to collaborate in a cohesive and coordinated fashion. It is true that one person, mentioned above, had some difficulties in carrying out the group work, but this was more the exception than the rule, as statements like the following were predominant:

"Well, even though sometimes there were disagreements, we ended up resolving our differences," (AL_COM, P101).

When asked about the performance of their classmates within the groups, most of the respondents reported that the other students had been cooperative and helpful (33), for example saying that "We helped 
each other both in class and when we had to study," (AL_GRUP, P43). Meanwhile, most students (102) expressed a belief that working with a team had enhanced their learning, with some (53) emphasising the support they received from classmates when they faced difficulties. The students felt the exposure to different points of view had enriched their experience and strengthened their acquisition of knowledge (23) and that the practice had fostered their organisiational skills (3).

"Yes, because everyone has their own point of view you learn things from everyone and do things in different ways," (APRE_GRUP, P79).

Some of the students identified the role played by the professor within the flipped classroom model as that of mentor (12) and guide (27) through the process. The professors' tasks mainly involved preparing the contents that would be covered in class (5) and answering questions (4). Many students pointed to the professor as a source of support (20) in the carrying out of activities and throughout the educational process, with one saying that the professor's role had been that of " $a$ guide. The professor guided us through the activities we were doing in class," (PROF_PAPEL, P79).

According to the students, the flipped classroom method brings with it improved communication with the professor (38). Many found their contact with the professor to be good/positive (38), very good (27) or close (5), thanks in part to the professor's willingness and eagerness to help (18).

"The communication with the professor was very good, and in large part that was because of the methodology, which mean that she interacted more with us," (PROF_ COM, P104).

It is worth highlighting the students' observation that the professor worked to serve their needs and answer any questions that came up during class (104), with one student noting that "Whenever we had doubts, she kindly resolved them," (PROF_INS, P81). The teacher also attended students' needs by providing them with clear instructions on how to carry out and participate in the tasks (103). One student, however, found that the professor was only sometimes able to respond to questions because activities were explained very quickly and there was a lack of communication. "Only sometimes. Not often, because the activities were explained in five minutes, and after that we didn't communicate anymore," (PROF_INS, P34).

Despite this critique, many students expressed satisfaction with the professors' performance, and 54 of them did not offer any suggestion for improvement, saying that the classes had been well taught and that they should continue to be offered in the same way in coming years. A minority of students, however, did highlight some aspects of the professors' performance that they believed could be improved, including:

The professor should explain the concepts bet-

ter so that the students can take notes (4): "Explain

the notes a little," (PROF_NED, P34).

She should be more attentive to the attitudes/ needs of the students (8). "She should pay more at- tention to the internal workings of the groups in order to detect problems and make sure that everyone is contributing to the group," (PROF_NED, P29),

Less flexible classes. (2): "I think that her classes are very enjoyable and you learn a lot, but it might be a good idea to give students a bit less freedom, because some people don't take the class seriously," (PROF_NED, P71).

To conclude this section, we have selected a quote that sums up the students' perception of the flipped classroom and interest in applying the model in the future as teachers.

"It was an enriching and entertaining experience, because it puts you into closer contact with your classmates. This way, you learn not only from the professor, but also from your classmates. I recommend this methodology, and if I have the chance I would like to put it into practice with my students," (MAT_PRO, P104).

\section{Discussion}

The students had a positive perception of the flipped classroom methodology and expressed the belief that the model had provided them with beneficial learning experiences (Awidi \& Paynter, 2019). Using this method leads to a student-centred learning environment, as it is the students who play the key role in the educational process as they construct their own learning via the work they do inside and outside the classroom (Zainuddi \& Perera, 2017).

The interviewees expressed an appreciation for the practical activities they carried out in class during their experience with the flipped classroom (Simón et al., 2016). They reported that having the chance to apply the course's theoretical contents to practical tasks had helped boost their motivation in class and led to meaningful learning (Serrano and Casanova, 2018), which is associated with improved academic performance and results (Akçayır \& Akçayır 2018; Sergi, Sampson, \& Pelliccione, 2018; Sola et al., 2019). The results also show that more than half of the students believed that the flipped classroom model had offered them the kind of individualised attention that allowed them to learn at their own pace (Tourón \& Santiago, 2015; Simón et al., 2016). Meanwhile, they also observed that the model encouraged them to adopt a more responsible and autonomous attitude with regard to their knowledge of the subject. The classroom was where they were able to attach full meaning to their learning and to get the help of the professor, who acted as a mediator between the students and the course contents (O’Flaherty \& Phillips, 2015; Perdomo, 2016; Simón et al., 2016).

These results are in accordance with an earlier study by Díaz, Martín and Sánchez (2017), which found the flipped classroom model to be an effective way to help students acquire a range of competencies. The previous study also concluded that the methodology helps improve academic results and enhances students' autonomy and motivation. For these reasons, students 
tend to express satisfaction and experience positive emotions throughout the process and to view this teaching model as more productive than traditional methodologies (González et al., 2018). Nonetheless, as McNally et al. (2017) pointed out, a small percentage of students are resistant to this methodology, mainly because of the changes in the roles of teachers and students that go along with it.

Meanwhile, the students singled out the fact that the flipped classroom incentivises collaborative work as one of the model's most useful aspects. This finding echoes an earlier study by Blasco et al. (2016). The students also attached a great deal of value to the group activities, which created an atmosphere of mutual support among classmates, who helped one another to overcome difficulties (Tourón \& Santiago, 2015). They students also believed that their learning process had benefitted from the discussion that went along with this teaching model, and they expressed appreciation for the rewarding relationships they had developed with their peers (Moraros et al., 2015). This study also reinforces prior findings by Evseeva and Solozhenko (2015), who reported that this educational model is associated with good classroom communication with the professor, who serves as a support and guide through students' learning process. Therefore, it would seem that in this model, relations between students and professors are better than they tend to be in more traditional classes.

As indicated above, the objective of this study was to determine the impact of the flipped classroom model on the teaching and learning process. The results show that the model has a positive impact on a number of different levels. Academically, the methodology is associated with improvements in both academic performance and grades. At the same time, the FC model helped the students develop a number of key competencies such as autonomy, responsibility, and organisational and teamwork skills, all of which they will apply in various facets of their future lives. In more personal terms, there seems to be a positive link between this pedagogical model and positive emotions, as well as between the model and greater motivation to learn. Finally, in terms of social effects, the model fosters relations between students through cooperative learning, and it helps establish a closer and more productive relationship between students and the professor, with the latter acting mainly as a guide. All of this can make a significant contribution to students' learning.

\section{Limitations of the study}

It is important to note that the data gathered in this case study cannot be generalised to other educational contexts or settings. The intention here was rather to understand and give meaning to the students' overall experience in this case. It is clear that a degree of intersubjectivity is inherent in the methodology used in this study that certainly affected the data analysis and may have led to certain biases in the information presented. These issues could have emerged from the researcher's interpretation of the data or from acquiescence or social desirability biases from the participants.

It is also true that the students might not have reflected their perceptions as thoroughly in writing as they would have orally. The study might have missed some relevant and important information as a result of the online data collection using the structured interview.

\section{Authors' statement}

The authors declare no conflicts of interest.

\section{References}

Akçayır, G \& Akçayır, M. (2018). The Flipped Classroom. A review of its advantages and challenges. Computer \& Education, 126, 334-345. doi:10.1016/j. compedu.2018.07.021

Andrade, E. \& Chacón, E (2018). Implicaciones teóricas y procedimentales de la clase invertida. Pulso: revista de educación, 41, 251-267.

Awidi, I. T. \& Paynter, M. (2019). The impact of a Flipped Classroom approach on student learning experience. Computers \& Education, 128, 269-283. doi:10.1016/j.compedu.2018.09.013

Betihavas, V., Bridgman, H., Kornhaber, R. \& Cross, M. (2016). The evidence for 'flipping out': a systematic review of the Flipped Classroom in nursing education. Nurse education today, 38, 15-21. doi:10.1016/j. nedt.2015.12.010

Blasco, A. C., Lorenzo, J. \& Sarsa, J. (2016). La clase invertida y el uso de vídeos de software educativo en la formación inicial del profesorado. Estudio Cualitativo. @tic. Revista d'innovació Educativa, 17, 12-20.

Chilingaryan, K. \& Zvereva, E. (2017). Methodology of Flipped Classroom as a learning technology in foreign language teaching. Procedia-Social and Behavioral Sciences, 237, 1500-1504. doi:10.1016/j.sbspro.2017.02.236

Díaz, E., Martín, M.L. \& Sánchez, J.M (2017). El impacto del Flipped Classroom en la motivación y en el aprendizaje de los estudiantes en la asignatura Dirección de Operaciones. Working Papers on Operations Management, 8, 15-18. doi:10.4995/wpom.v8i0.7091

Evseeva, A. \& Solozhenko, A. (2015). Use of Flipped Classroom technology in language learning. ProcediaSocial and Behavioral Sciences, 206, 205-209. doi:10.1016/j.sbspro.2015.10.006

Goedhart, N. S., Blignaut-van, N., Moser, C. \& Zweekhorst, M. B. M. (2019). The Flipped Classroom: supporting a diverse group of students in their learning. Learning Environments Research, 22(2) 1-14. doi:10.1007/s10984-019-09281-2

González, N. \& Carrillo, G, A. (2016). El Aprendizaje Cooperativo y la Flipped Classroom: una pareja ideal mediada por las TIC. Revista digital de comunicación. 5(2), 043-048. 
González, D., Jeong, J. S., Gallego, A. \& Cañada, F. (2018). Influencia de la metodología flipped en las emociones sentidas por estudiantes del Grado de Educación Primaria en clases de ciencias dependiendo del bachillerato cursado. Educación química, 29(1), 77-88. doi:10.22201/fq.18708404e.2018.1.63698

Jensen, J. L., Holt, E. A., Sowards, J. B., Ogden, T.H, \& West, R. E. (2018). Investigating Strategies for PreClass Content Learning in a Flipped Classroom. Journal of Science Education and Technology, 27(6), 523-535. doi:10.1007/s10956-018-9740-6

Long, T., Cummins, J. \& Waugh, M. (2016). Use of the Flipped Classroom instructional model in higher education: instructors' perspectives. Journal of Computing in Higher Education, 29(2), 1-22.

Lundin, M., Rensfeldt, A. B., Hillman, T., Lantz-Andersson, A., \& Peterson, L. (2018). Higher education dominance and siloed knowledge: a systematic review of Flipped Classroom research. International Journal of Educational Technology in Higher Education, 15(1), 1-30. doi:10.1186/s41239-018-0101-6

Luo, H., Yang, T., Xue, J., \& Zuo, M. (2019). Impact of student agency on learning performance and learning experience in a Flipped Classroom. British Journal of Educational Technology, 50(2), 819-831. doi10.1111/bjet.12604

Martín, D. \& Núñez Del Río, Ma C. (2015). Una experiencia Flipped Classroom en educación superior: la formación del profesorado de secundaria. Investigar con y para la sociedad, 3, 1717-1729.

Martín, D. \& Santiago, R. (2016). Flipped Learning en la formación del profesorado de secundaria y Bachillerato. Formación para el cambio. Contextos educativos. $N^{o}$ extraordinario 1, 117-134.

McNally, B., Chipperfield, J., Dorsett, P., Del Fabbro, L., Frommolt, V., Goetz, S., Lewohl, J., Molineux, M., Pearson, A., Reddan, G., Roiko, A. \& Rung, A. (2017). Flipped classroom experiences: student preferences and flip strategy in a higher education context. Higher Education, 73(2), 281-298. doi:10.1007/s10734016-0014-Z

Moraros, J., Islam, A., Yu, S., Banow, R., \& Schindelka, B. (2015). Flipping for success: evaluating the effectiveness of a novel teaching approach in a graduate level setting. BMC medical education, 15(1), 1-10. doi:10.1186/s12909-015-0317-2

O'Flaherty, J. \& Phillips, C. (2015). The use of Flipped Classrooms in higher education: A scoping review. The Internet and Higher Education, 25, 85-95. doi:10.1016/j.iheduc.2015.02.002

Perdomo, W. (2016). Estudio de evidencias de aprendizaje significativo en un aula bajo el modelo Flipped Classroom. Edutec. Revista Electrónica de Tecnología Educativa, 55, 1-17. doi:10.21556/edutec.2016.55.618

San Martín, D. (2014). Teoría fundamentada y Atlas.ti: recursos metodológicos para la investigación educativa. Revista Electrónica de Investigación Educativa, 16(1), 104-122.

Sánchez, J, Ruiz, J, \& Sánchez, E, (2017). Flipped classroom. Claves para su puesta en práctica. Revista de
Educación Mediática y TIC, 6(2), 336-358. doi:10.21071/ edmetic.v6i2.5832

Sánchez, M. M., Solano, I. M. \& González, V. (2016). FLIPPED-TIC: Una experiencia de Flipped Classroom con alumnos de Magisterio. Revista Latinoamericana de tecnología educativa (RELATEC), 15(3), 69-81. doi:10.17398/1695-288X.15.3.69

Sergis, S., Sampson, D. G. \& Pelliccione, L. (2018). Investigating the impact of Flipped Classroom on students' learning experiences: A Self-Determination Theory approach. Computers in Human Behavior, 78, 368-378. doi:10.1016/j.chb.2017.08.011

Serrano, R. M. \& Casanova, O. (2018). Recursos tecnológicos y educativos destinados al enfoque pedagógico Flipped Learning. REDU. Revista de Docencia Universitaria, 16(1), 155-173. doi:10.4995/redu.2018.8921

Simon, J., Ojando, E. S., Ávila, X., Prats, M. À. \& Miralpeix, A. (2018). Percepció dels estudiants i del professorat del Grau d'Educació Primària de Blanquerna - Universitat Ramon Llull sobre la incorporació experimental de la flipped classroom. Aloma. Revista de Psicología, Ciències de l’Educació i de l’Esport. 34 (1), 45-52.

Simon, J., Ojando, E. S., Ávila, X., Miralpeix, A., López, P., \& Prats, M. À. (2018). Reformulación de los roles del docente y del discente en la educación. El caso práctico del modelo de la Flipped Classroom en la universidad. Revista de Estudios y Experiencias En Educación, 2(1), 53-73. doi:10.21703/rexe.Especial2_201853733

Sola, T., Aznar, I., Romero J. M., \& Rodríguez, A. M. (2019). Eficacia del Método Flipped Classroom en la Universidad: Meta-Análisis de la Producción Científica de Impacto. REICE. Revista Iberoamericana sobre Calidad, Eficacia y Cambio en Educación, 17(1), 25-38.

Sosa Díaz, M. J. \& Palau, R. (2018a). Flipped classroom para adquirir la competencia digital docente: una experiencia didáctica en la Educación Superior. PixelBit, 52, 37-54.

Sosa, M. J. \& Palau, R. F. (2018b). Flipped Classroom en la Formación Inicial del Profesorado: Perspectiva del alumnado. REDU. Revista de Docencia Universitaria, 16(2), 249-264. doi:10.4995/redu.2018.7911

Strauss, A., \& Corbin, J. (2002). Bases de la investigación cualitativa. Técnicas y procedimientos para desarrollar la teoría fundamentada. Colombia: Universidad de Antioquia.

Strayer, J. F. (2012). How learning in an inverted classroom influences cooperation, innovation and task orientation. Learning Environments Research, 15(2), 171-193.

Sun, C. Y., \& Wu, Y. T. (2016). Analysis of learning achievement and teacher-student interactions inflipped and conventional classrooms. International Review of Research in Open and Distance Learning, 17(1), 79-99. doi:10.19173/irrodl.v17i1.2116

Tourón, J., \& Santiago, R. (2015). El modelo Flipped Learning y el desarrollo del talento en la escuela. Revista de Educación, 368, 196-231. doi:10.4438/1988592X-RE-2015-368-288 
Yoshida, H. (2016). Perceived Usefulness of "Flipped Learning" on instructional design for elementary and secondary education: with focus on pre-service teacher education. International Journal of Information and Education Technology, 6(6), 430- 434. doi:10.7763/ IJIET.2016.V6.727
Zainuddin, Z., \& Perera, C. J. (2017). Exploring students' competence, autonomy and relatedness in the Flipped Classroom pedagogical model. Journal of Further and Higher Education, 43(1), 115-126. doi:10 .1080/0309877X.2017.1356916 